\title{
Transpalatine Route for the Correction of Transsphenoidal Encephalocele in a Child: A Case Report and Literature Review
}

\section{Via transpalatina para correção de encefalocele transesfenoidal em uma criança: relato de caso e revisão da literatura}

\author{
Aldo José F. da Silva ${ }^{1}$ Fabrício A. C. Lopes ${ }^{1}$ \\ ${ }^{1}$ Division of Pediatric Neurosurgery, General State Hospital (GSH), \\ Maceió, AL, Brazil \\ Address for correspondence Aldo José F. da Silva, MD, R. Barão José \\ Miguel 151, 57055160, Maceió, Brazil \\ (e-mail: neuroajfs@yahoo.com.br).
}

Arq Bras Neurocir 2017;36:234-237.

\begin{abstract}
Keywords

- encephalocele

- transpalatine

- transsphenoidal

- meningoceles
\end{abstract}

\section{Resumo}

Introduction Transsphenoidal encephalocele is a rare neural tube defect characterized by the herniation of meninges and eventually of parts of the brain through a bony defect in the sphenoid bone. The clinical presentation is variable, and surgical treatment is controversial.

Case Report This report describes the case of an 8-month-old female child diagnosed with transsphenoidal encephalocele. The child presented with obstruction of the upper airways and was fed via a nasogastric tube but did not present changes in the hypothalamic-pituitary-axis. The patient underwent surgery with the transsphenoidal-transpalatine route, with an excellent outcome and without fistulas or infections. Conclusions Although transsphenoidal encephalocele is a rare congenital anomaly, the transsphenoidal-transpalatine route for the correction of this type of encephalocele is a safe option and produces a favorable outcome in pediatric patients.

Introdução A encefalocele transesfenoidal é um defeito do tubo neural raro, caracterizado por herniação de meninges e eventualmente partes do cérebro através de uma falha óssea no osso esfenoide. A apresentação clínica é variável e o tratamento cirúrgico é controverso.

Relato de Caso No presente trabalho descrevemos o caso de uma criança de 8 meses, sexo feminino, com diagnóstico de encefalocele transesfenoidal. Apresentava-se com obstrução de vias aéreas superiores, alimentando-se por sonda nasoenteral e sem alterações do eixo hipotálamo-hipofisário. Tratada com cirurgia via transesfenoidal transpalatal, evoluiu com excelente resultado, sem fístulas e sem infecções.

Conclusões Embora a encefalocele transesfonoidal seja uma anomalia congênita rara, a via transpalatina-transesfenoidal para correção deste tipo de encefalocele é uma opção segura e produz um resultado favorável no paciente pediátrico. received

July 13,2017

accepted

September 19, 2017

published online

December 7, 2017
DOI https://doi.org/

10.1055/s-0037-1607999. ISSN 0103-5355.
Copyright (e 2017 by Thieme Revinter

Publicações Ltda, Rio de Janeiro, Brazil
License terms

c) $(1) \$$ 


\section{Introduction}

Encephalocele consists of the herniation of parts of the intracranial contents through a bony defect in the skull. Cranial meningoceles involve cases in which the content of the herniated sac is composed of meninges, delimiting a sac containing cerebrospinal fluid (CSF). ${ }^{1}$

The incidence of encephalocele is approximately one case per 3,000-5,000 live births. ${ }^{2-4}$ Basal encephaloceles are less common, with an incidence of one case per 35,000 live births. ${ }^{5-7}$ Basal encephaloceles are classified into transethmoidal, spheno-orbital, sphenomaxillary, and transsphenoidal.

The transsphenoidal type represents less than $5 \%$ of all cases of basal encephalocele, with an incidence of one in 700,000 live births. ${ }^{8}$

The treatment is controversial because of the rarity of the condition. Herein we present the case of an 8-month-old child operated via the transsphenoidal-transpalatine route.

\section{Case Report}

An 8-month-old female child presented with difficulty in breathing (respiration via tracheostomy) and difficulty in feeding (fed via a nasogastric tube). Oroscopy indicated bulging of the palate without evidence of cleft palate. The endocrinological and ophthalmological examinations were unremarkable. Cranial computed tomography (CT) and magnetic resonance imaging (MRI) revealed sphenoid bone defect ( - Fig. 1) with the presence of transsphenoidal meningoencephalocele (-Fig. 2).

The patient underwent surgical correction of the malformation via the transsphenoidal-transpalatine route (-Fig. 3 ). Under general anesthesia, a midline incision was made in the soft palate until the limit of the hard palate. This procedure was followed by the dissection of the mucosa and the herniated sac, and the reduction of the herniated sac to a minimum by bipolar

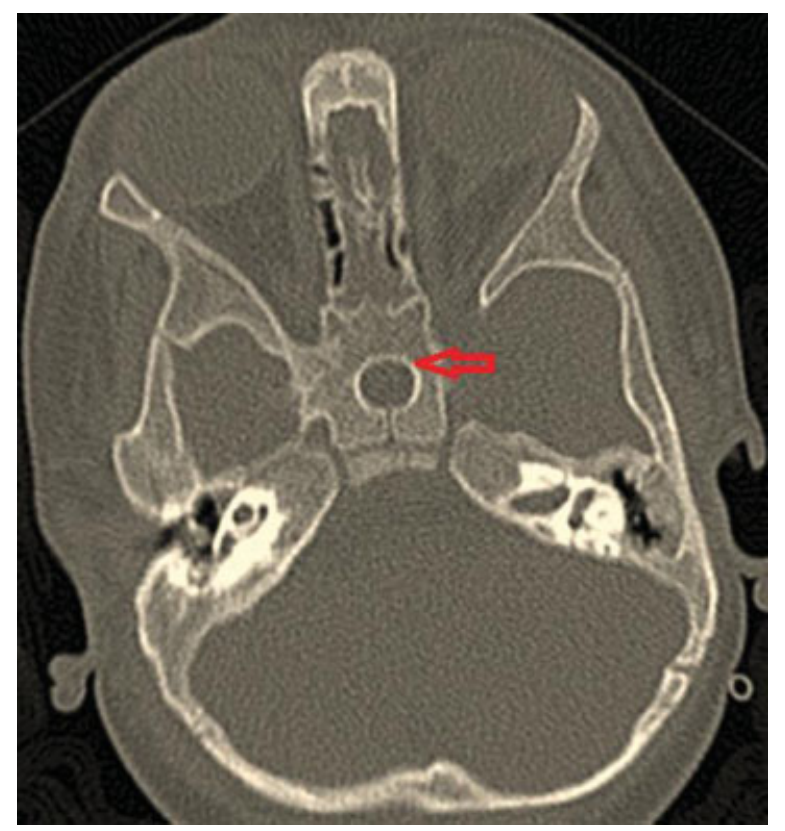

Fig. 1 Axial computed tomography (CT) scan with sphenoid bone defect (arrow).

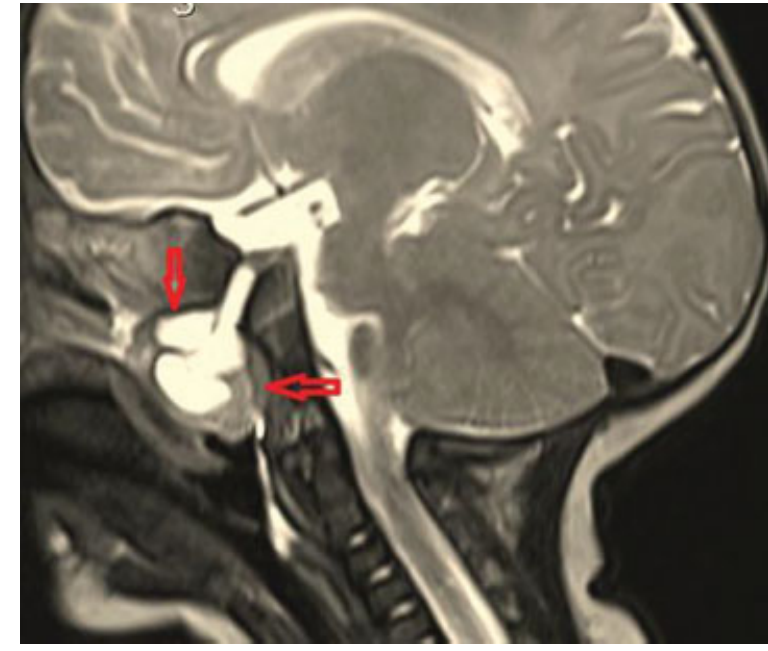

Fig. 2 Sagittal T2-weighted magnetic resonance imaging (MRI) showing (arrows) transsphenoidal meningoencephalocele.

coagulation without opening the dura mater. After marking the edges of the bone defect, an incision was made in the herniated sac, a segment of the sac was resected, and the sac was closed with a reinforcement suture. Then, Surgicel (Ethicon, Somerville, NJ, USA), a hemostatic sponge, and a dural sealant were used. Postoperatively, the clinical course of the patient was uneventful (without bleeding, fistulae, or endocrinological changes). On the fifth postoperative day, the patient was decannulated, and she could spontaneously breathe again (-Fig. 4). On the 15th postoperative day, the nasogastric tube was removed, and the patient began to eat via the oral route without gagging.

\section{Discussion}

Several theories have been proposed to explain the formation of transsphenoidal encephalocele. The classical theory postulates that the lack of separation of the neuroectoderm from the

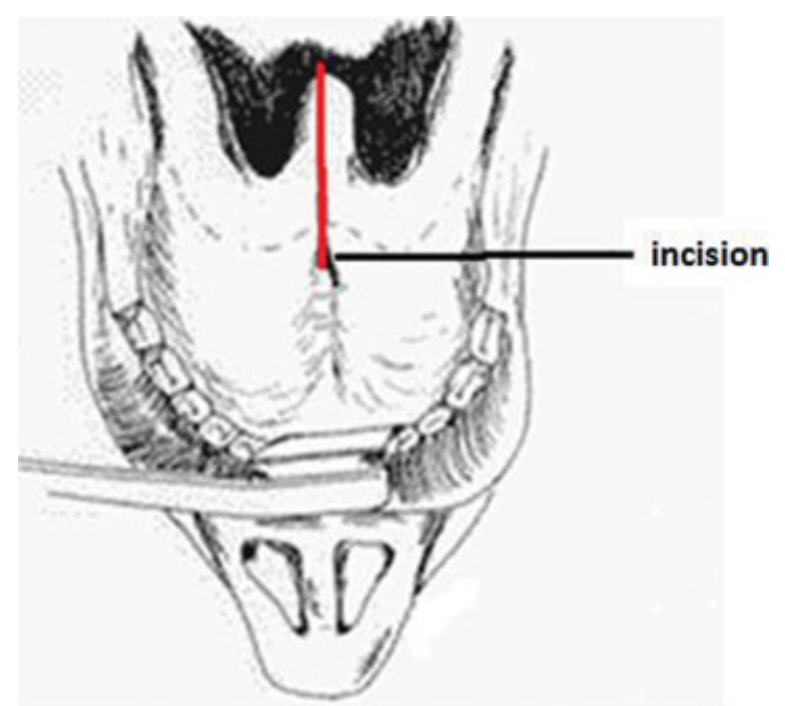

Fig. 3 Transsphenoidal-transpalatine approach. 


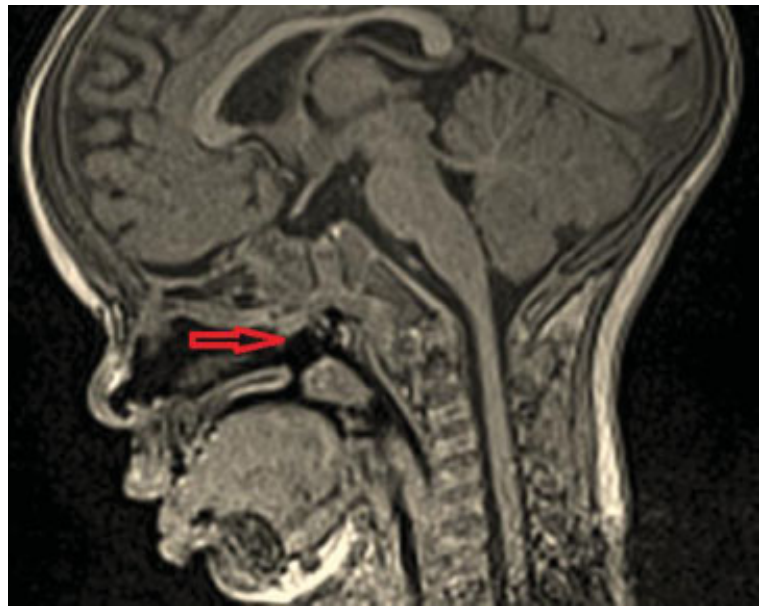

Fig. 4 Sagittal T1-weighted magnetic resonance imaging (MRI) showing the status after treatment with permeabilization of the upper airways (arrow).

ectodermal surface during the formation of the neural tube prevents the insertion of the mesodermal tissue between the two germ layers and causes changes in the skull ossification, as well as a secondary herniation. ${ }^{9,10}$ Another theory states that the incomplete closure of the neural tube, together with the herniation of the meninges and neural tissue, may be due to a persistent craniopharyngeal canal. ${ }^{8,11,12}$

Transsphenoidal encephalocele is associated with abnormalities in the development of the face, the optical system, and the encephalon. ${ }^{10,13-15}$ Facial malformations are usually present and involve hypertelorism, median nasal fissure, enlarged nasal base, cleft lip or palate, median cleft face syndrome, or occult frontal cranium bifidum. 7,16,17 Optical abnormalities include anophthalmia or microphthalmia, coloboma, retinal abnormalities, and hypoplasia of the optical nerve or chiasm. ${ }^{16,18}$ Brain changes include agenesis of the corpus callosum (in more than $50 \%$ of cases), hydrocephalus, and pituitary dystopia or hypoplasia. ${ }^{19-21}$

Transsphenoidal encephalocele is usually asymptomatic or is occasionally diagnosed, and the most common presentation is the presence of a mass in the cranial midline. ${ }^{10}$ Clinical manifestations, when present, depend on the age of the patient. ${ }^{16}$ In the absence of facial changes, the diagnosis can be made in adolescence or adulthood in cases in which rhinorrhea, meningitis, or unexplained progressive visual defect require examination and diagnosis. ${ }^{5,7,22}$ Other complications may occur, including hypothyroidism, growth retardation, hypogonadism, or diabetes insipidus. ${ }^{16,22,23}$ The sphenoid bone defect may cause herniation of intracranial structures, including the third ventricle, segments of the hypothalamus and pituitary gland, anterior cerebral arteries, or optical chiasm. ${ }^{5,7,16,23}$ Considering that the tissue is a nasal mass, the differential diagnosis for glioma, dermoid cysts, and polyps should be considered. ${ }^{24}$

Imaging studies are essential for the confirmation of diagnosis and the evaluation of the contents of the herniated sac. ${ }^{25}$ Non-contrast CT scans with three-dimensional reconstruction should be conducted to evaluate the defect at the skull base. Magnetic resonance imaging should also be conducted to determine the constituents of the herniated sac. ${ }^{26}$ Digital angiography or magnetic resonance angiography are not routinely used, but may be considered in cases in which the MRI suggests the involvement of the anterior cerebral arteries. ${ }^{27}$

In the past, many cases of basal encephalocele were wrongly treated as tumors or nasal polyps, resulting in high mortality because of CSF rhinorrhea and meningitis. ${ }^{1}$ At present, because of the rarity of transsphenoidal encephalocele and the small number of cases reported in the literature, standardization of treatment is controversial. ${ }^{4,7,16}$ Surgical intervention is indicated in cases of airway obstruction and CSF rhinorrhea or meningitis attributed to the lesion. ${ }^{28}$ In asymptomatic individuals and in those with hormonal changes or stable visual deficit, the indications for repair are less clear. ${ }^{5,7,16}$ Some authors argue that early repair reduces the risk of infection, the growth of the encephalocele, and the risk of trauma to the herniated sac. ${ }^{16,29}$

The use of the transcranial access in the treatment of transsphenoidal encephalocele remains controversial, especially in neonates and children. ${ }^{28}$ Some studies have shown that the transcranial access, with retraction of the frontal lobe and elevation of the herniated elements via sella turcica, with or without resection of the cephalocele and its contents, is associated with high rates of hypothalamic dysfunction, morbidity, and mortality. ${ }^{7,29}$ Moreover, the use of this route increases the complexity of the surgery because of the involvement of important blood vessels and nerves located in the area of transcranial access. ${ }^{27}$

In a few select cases, transnasal endoscopic surgery may be an optional treatment, particularly for transsphenoidal encephaloceles with a small neck. ${ }^{1}$ Its use is well described in adult patients, but less common in pediatric patients, for which there are fewer descriptions in the literature. ${ }^{30}$

The transsphenoidal-transpalatine approach is an acceptable strategy, without reports of fatality, despite the higher risk of infection due to the incomplete repair of the dura mater. ${ }^{16,31}$

The choice of correction for the described case was via the transsphenoidal-transpalatine route. This was possible because, although the child did not have a cleft palate, we believed that this access route was appropriate for her age and could result in excellent dural closure. Our patient did not present hypothalamic-pituitary dysfunction, and we believe that this was either due to the small size of the sphenoid bone defect or due to us carefully cauterizing the herniated sac to reduce its size to the maximum before opening it for correction. This strategy prevented greater CSF leakage and consequently herniation of the pituitary gland.

\section{Conclusion}

Although transsphenoidal encephalocele is a rare congenital anomaly, with no consensus on treatment, the transsphenoidal-transpalatine route is a safe option for the described age. Moreover, a favorable outcome can be achieved with follow-up by a multidisciplinary team.

\section{Conflict of Interest}

On behalf of all authors, the corresponding author states that there is no conflict of interest. 


\section{References}

1 Matushita H. Encefaloceles. In: Diament A, et al. Child Neurology. $5^{\text {th }}$ ed. São Paulo: Atheneu; 2010:795-810

2 Abe T, Lüdecke DK, Wada A, Matsumoto K. Transsphenoidal cephaloceles in adults. A report of two cases and review of the literature. Acta Neurochir (Wien) 2000;142(04):397-400

3 David DJ, Proudman TW. Cephaloceles: classification, pathology, and management. World J Surg 1989;13(04):349-357

4 Matson DD. Neurosurgery of Infancy and Childhood. 2nd ed. Springfield, I11: Charles C Thomas; 1969:68

5 Smith DE, Murphy MJ, Hitchon PW, Babin RW, Abu-Yousef MM. Transsphenoidal encephaloceles. Surg Neurol 1983;20(06): 471-480

6 Vannouhuys JM, Bruyn GW. Nasopharyngeal transphenoidal encephalocele, crater like hole in the optic disc and agenesis of the corpus callosum. Pneumoencephalographic visualisation in a case. Psychiatr Neurol Neurochir 1964;67:243-258

7 Yokota A, Matsukado Y, Fuwa I, Moroki K, Nagahiro S. Anterior basal encephalocele of the neonatal and infantile period. Neurosurgery 1986;19(03):468-478

8 Jabre A, Tabaddor R, Samaraweera R. Transsphenoidal meningoencephalocele in adults. Surg Neurol 2000;54(02):183-187, discussion 187-188

9 Blustajn J, Netchine I, Frédy D, Bakouche P, Piekarski JD, Meder JF. Dysgenesis of the internal carotid artery associated with transsphenoidal encephalocele: a neural crest syndrome? AJNR Am J Neuroradiol 1999;20(06):1154-1157

10 Mylanus EAM, Marres HAM, Vlietman J, et al. Transalar sphenoidal encephalocele and respiratory distress in a neonate: a case report. Pediatrics 1999;103(01):E12

11 Buchfelder M, Fahlbusch R, Huk WJ, Thierauf P. Intrasphenoidal encephaloceles-a clinical entity. Acta Neurochir (Wien) 1987;89 (1-2):10-15

12 Hasegawa S, Hayashi N, Kubo M, et al. Basal encephalocele associated with hypoplasia of the internal carotid artery. Neurol Med Chir (Tokyo) 2007;47(12):572-575

13 Larsen CE, Hudgins PA, Hunter SB. Skull-base meningoencephalocele presenting as a unilateral neck mass in a neonate. AJNR Am J Neuroradiol 1995;16(05):1161-1163

14 Diebler C, Dulac O. Cephaloceles: clinical and neuroradiological appearance. Associated cerebral malformations. Neuroradiology 1983;25(04):199-216

15 Elster AD, Branch CLJr. Transalar sphenoidal encephaloceles: clinical and radiologic findings. Radiology 1989;170(1 Pt 1):245-247
16 Kennedy EM, Gruber DP, Billmire DA, Crone KR. Transpalatal approach for the extracranial surgical repair of transsphenoidal cephaloceles in children. J Neurosurg 1997;87(05):677-681

17 DeMyer W. The median cleft face syndrome. Differential diagnosis of cranium bifidum occultum, hypertelorism, and median cleft nose, lip, and palate. Neurology 1967;17(10):961-971

18 Goldhammer Y, Smith JL. Optic nerve anomalies in basal encephalocele. Arch Ophthalmol 1975;93(02):115-118

19 Pollock JA, Newton TH, Hoyt WF. Transsphenoidal and transethmoidal encephaloceles. A review of clinical and roentgen features in 8 cases. Radiology 1968;90(03):442-453

20 Mahapatra AK. Anterior encephaloceles. Indian J Pediatr 1997;64 (05):699-704

21 Raman Sharma R, Mahapatra AK, Pawar SJ, Thomas C, Al-Ismaily M. Trans-sellar trans-sphenoidal encephaloceles: report of two cases. J Clin Neurosci 2002;9(01):89-92

22 Soyer P, Dobbelaere P, Benoit S. Transalar sphenoidal encephalocele. Uncommon clinical and radiological findings. Clin Radiol 1991;43(01):65-67

23 Ellyin F, Khatir AH, Singh SP. Hypothalamic-pituitary functions in patients with transsphenoidal encephalocele and midfacial anomalies. J Clin Endocrinol Metab 1980;51(04):854-856

24 Hoving EW. Nasal encephaloceles. Childs Nerv Syst 2000;16 (10-11):702-706

25 Holanda MMA, Rocha AB, Santos RHP, et al. Basal Sphenoethmoidal encephalocele in association with midline cleft lip and palate: case report. Radiol Bras 2011;44(06):399-400

26 Rathore YS, Sinha S, Mahapatra AK. Transsellar transsphenoidal encephalocele: a series of four cases. Neurol India 2011;59(02):289-292

27 Cohen AR. Encephaloceles of the anterior cranial base. In Rengachary S, Wilkins R (eds): Neurosurgical operative atlas. American Association of Neurological Surgeons. Baltimore: Williams and Wilkins; 1992:367-375

28 Tsutsumi K, Asano T, Shigeno T, Matsui T, Ito S, Kaizu H. Transcranial approach for transsphenoidal encephalocele: report of two cases. Surg Neurol 1999;51(03):252-257

29 David DJ. Cephaloceles: classification, pathology, and management-a review. J Craniofac Surg 1993;4(04):192-202

30 Ayoub JAS, Xavier PFF, Stamm AC, et al. Sphenopalatine Meningoencephalocele: A diagnosis and therapeutic Challenge - report case. Int Arch Otorhinolaryngol 2010;14:127-130

31 Lewin ML. Sphenoethmoidal cephalocele with cleft palate: transpalatal versus transcranial repair. Report of two cases. J Neurosurg 1983;58(06):924-931 